\title{
КОНЦЕПЦИЯ ЧЕЛОВЕКА КАК ОРИГИНАЛЬНОЕ АНТРОПОЛОГИЧЕСКОЕ УЧЕНИЕ В.И. НЕСМЕЛОВА
}

\section{HUMAN CONCEPT AS AN ORIGINAL ANTHROPOLOGICAL TEACHING OF V.I. NESMELOV}

\section{G. Fisenko}

Summary: The article reveals the main provisions of the concept of man, which he developed at the turn of the XIX-XX centuries russian religious philosopher V.I. Nesmelov, who presented it primarily in the work "The Science of Man". It is noted that the main position, which is put forward by the philosopher from the point of view of metaphysical psychology, is the presence of physical and ideal components in the structure of a human personality. The contradiction of the personality that determines the life of a person consists in the fact that he is forced to exist in a physical shell and cannot escape from the clutches of the material, while fully realizing his ideal nature and direct connection with God. This contradiction dictates the author's interpretation of the concepts of human happiness and unhappiness, self-awareness in the structure of his personality, his conscience and morality, freedom, the relationship between physical and spiritual principles, life, death and resurrection.

Keywords: Victor Nesmelov, "The Science of Man", Russian religious anthropology, metaphysical psychology, human concept, personality.
$\Phi$ илософское наследие Виктора Ивановича Несмелова (1863-1937), незаслуженно забытое в советский период развития русской философии, получает сегодня новое осмысление. К наиболее значимым научным достижениям этого русского религиозного философа и антрополога относится разработанная им и представленная в двухтомном труде «Наука о человеке» концепция человека.

Компоненты данной концепции рассматривают многие современные философы. М.Я. Дворецкая и А.О. Турина анализируют трактовку автором смысла жизни [4] и структуры и развития самосознания человека [5], А.В. Белов выявляет особенности понимания философом идеи субъектности [1], А.А. Сулема - проблемы телесности [10], А.П. Шпак - проблемы счастья [11]. Разработанной автором концепции, именуемой «метафизикой человека», посвятили свои изыскания В.Н. Замилов [6] и В.А. Поль [9]. К проблеме человека, и её пониманию В.И. Несмеловым обращается в своём исследовании А.В. Добин [5]. В современной науке появилась необходимость системного описания концепции человека, предложенной В.И. Несмеловым, выявления связей между различными элементами этой системы и установления
Фисенко Григорий Федорович

Аспирант, Тульский государственный педагогический университет имени Л.Н. Толстого

vipger@bk.ru

Аннотация: В статье выявлены основные положения концепции человека, разработанной русским религиозным философом рубежа XIX-XX вB. В.И. Несмеловым и представленной им в первую очередь в труде «Наука о человеке». Отмечается, что основным положением, которое с точки зрения метафизической психологии выдвигает философ, является наличие в структуре человеческой личности физической и идеальной составляющих. Противоречие личности, определяющее жизнь человека, состоит в том, что он вынужден существовать в физической оболочке и не может вырваться из тисков материального, одновременно полностью осознавая свою идеальную природу и прямую связь с Богом. Данное противоречие диктует трактовку автором понятий счастья и несчастья человека, самосознания в структуре его личности, его совести и нравственности, свободы, соотношения физического и духовного начал, жизни, смерти и воскресения.

Ключевые слова: Виктор Несмелов, «Наука о человеке», русская религиозная антропология, метафизическая психология, концепция человека, личность.

значимости каждого элемента, что поможет понять суть данного учения, являющегося важным с точки зрения не только истории развития русской философии, но и её современного состояния.

Целью настоящего исследования стало выявление основных положений концепции человека, предложенной В.И. Несмеловым. Основным принципом анализа стал историко-философский, также использовались методы анализа и синтеза, интеграции и дифференциации, описания и наблюдения и др. Исследование проводилось на материале книги В.И. Несмелова «Наука о человеке» $[7 ; 8]$.

Сам В.И. Несмелов начинает разговор о разрабатываемой им концепции человека с введения понятия «загадка человека», которое становится ключевым для его концепции. С помощью данного термина автор обозначает проблему сущности человеческой личности и связанных с этой сущностью вопросов самосознания, самопознания и назначения человека. В.И. Несмелов очень высоко оценивает способности человека к познанию мира (современная ему наука демонстрировала умение человека раскрывать загадки природы одну за другой, 
и философ осознавал важность этих достижений), но заявляет о том, что основная загадка лежит внутри самого человека, в структуре его личности: «Для человека не существует в мире никаких загадок, кроме самого человека, и сам человек является для себя загадкой лишь в том единственном отношении, что природа его личности по отношению к данным условиям его существования оказывается идеальной» [7, с. 241]. Это та загадка, которую, по мнению философа, оказалась неспособной раскрыть естественная наука, при всей своей силе и исключительно динамичном развитии.

В.И. Несмелов в своей «Науке о человеке» предлагает решение данной загадки, для чего, собственно, и выстраивает свою концепцию человека.

Основное положение, из которого исходят все остальные структурные элементы концепции, состоит в том, что в человеческой личности выделяются две составляющие - физическая и идеальная. В целом данное положение высказывается в русле христианского постулата о теле и духе, о материальном и идеальном, однако в её развитии В.И. Несмелов проявляет оригинальный подход. Он говорит о зависимости человека от его физической формы, которая требует от него постоянных усилий по обеспечению своего физического существования: «...Хлеб существует ради питания человека, а сам человек существует ради добывания хлеба» [Там же, с. 243]. По мнению В.И. Несмелова, человек обречён на эту вечную зависимость, неспособен не только от неё освободиться, но и даже как-то её ослабить, не может «осуществить себя как свободно-разумную личность в физическом содержании жизни» [Там же]. В то же время он осознаёт духовно-идеальную сторону своей природы, ощущает в структуре своей личности представление о Боге и стремление к нему. Понимая свою идеальную сущность, человек стремится «развить свою жизнь из одних только идеальных определений своей духовной природы» [Там же, с. 243-244], но не может этого сделать, поскольку ограничен, связан физической формой, материальностью своего существования.

В результате создаётся «роковое противоречие», формулируемое В.И. Несмеловым следующим образом: «...Человек никогда не может сделать себя тем, чем он должен быть, потому что ради этого ему пришлось бы перестать быть тем, что он есть, т. е., значит, - ему вообще пришлось бы перестать быть» [Там же, с. 244]. Вся жизнь человека, по В.И. Несмелову, находится в зависимости от этого противоречия; оно делает существование человека очень сложным, лишает его возможности быть спокойным и умиротворённым, вносит в его жизнь сумбур в мыслях и действиях, заставляет человека постоянно испытывать муки от невозможности вырваться их пут физического существования и полностью, безраздельно приобщиться к идеальному существованию, которое че- ловек осознаёт и к которому непрерывно рвётся.

Данное роковое противоречие влияет на все аспекты жизни человека и развития его личности.

Оно определяет то, что для человека недостижимо счастье, к которому он постоянно стремится. Человек хочет найти счастье в материальном, но не может его достичь, поскольку идеальное его Я остаётся при этом ненаполненным; счастье же идеального Я, божественной природы недостижимо в силу необходимости каждодневного внимания к физической жизни человека, поскольку зависит «не от него самого, а от разных посторонних условий» $[7$, с. 225].

Счастью противостоит страдание, заменяет его. Оно присутствует в жизни человека на всём её протяжении именно потому, что человек вынужден существовать в физическом мире, испытывая при этом «одну только невыносимую муку» [Там же, с. 198]. Человек пытается избежать страданий и получить наслаждения, но сталкивается с тем, что удовольствие физическое означает страдание духовное, усиливает понимание несоответствия человека идеальной части его природы.

Для личности человека, понимающего свою двойственную природу, по В.И. Несмелову, важнейшим явлением и основным внутренним действием становится самосознание, представляющее собой «познание человеком себя самого и своей цели в мире именно под углом сознания той самой неведомой связи, которая заставляет человека чувствовать себя, как будто он находится в постоянном присутствии Бога» [8, с. 135]. В психологической концепции человека В.И. Несмелова сознание и самосознание не только теснейшим образом связаны и не могут существовать одно без другого, это по сути одно и то же. Самосознание помогает человеку не только уяснить существование в структуре своей личности двух противоположных начал, но и попытаться примирить их друг с другом, осознать ключевое противоречие собственной жизни.

Результатом самосознания, по В.И. Несмелову, становится совесть, которую философ характеризует как «чувство душевного удовольствия в человеке» [7, с. 238]. Совесть должна составить для человека «действительное содержание его жизни», она есть «сознание должного..., нравственное чувство, нравственный закон» [Там же]. Совесть определяет отношение человека к своей идеальной стороне, к Христу, понимание религии; она есть результат постижения сложного соотношения физического и идеального. Совесть выступает как проявление нравственности, которое призвано заменить «физический принцип человеческой жизни» [Там же, с. 234], когда человек полностью осознает свою двойственную природу. И вот с развитием своих совести и нравствен- 
ности человек уже имеет возможность стать немного ближе к Богу, опираться на идеальную составляющую своей личности, по-прежнему не имея при этом возможности отвергнуть физическую.

Нравственность человека при этом выступает как явление, естественное для его природы. Она не навязывается извне, какими-то внешними, общественными или религиозными правилами, а формируется лишь в результате осознания своей природы, постижения идеальной составляющей совей жизни.

Физическое и духовное в человеке в концепции В.И. Несмелова выступают как совершенно естественные, данные природой и при этом абсолютно непримиримые начала. По мнению учёного, в физическом организме человека «...нельзя отыскивать какого-нибудь седалища духа» [7, с. 164], то есть тело не является вместилищем духа; эти начала вообще несовместимы и при этом оба присутствуют в человеке, что делает его несчастным. Духовная часть личности, по В.И. Несмелову, должна преобладать над телесной, в этом случае нравственное начало усиливается. Однако вытеснить физическое полностью духовность не сможет, и человек всегда будет оставаться противоречивым и несчастным существом, не способным при жизни избавиться от своего противоречия.

Важнейшим компонентом структуры личности человека, вынужденного постоянно испытывать несчастье от противоречия своей природы, по В.И. Несмелову, является свобода. Учёный считает, что человек не может обрести свободу, поскольку она присуща ему изначально, является частью его сущности. При этом степень свободы у каждого человека может быть разной и зависит от уровня осознания им собственной идеальной составляющей, от развития нравственности и совести. Человек обретает свободу в результате самосознания, и она становится «реальной силой его для внутреннего развития человеческой личности» $[7$, с. 180]. Человек не может существовать без свободы, поэтому его стремление к свободе, так явно наблюдавшееся В.И. Несмеловым и его современниками на рубеже XIX-XX вв., является вполне естественным.

Для концепции человека В.И. Несмелова очень важным понятием становится смерть. Поскольку человек не может вырваться из тисков физического в течение жизни, не способен обрести счастье и спокойствие, то только смерть выступает тем состоянием, в котором может содержаться решение этой проблемы. В.И. Несмелов трактует смерть как желаемое состояние, в котором человек избавляется от своего противоречия и обретает счастье. В этой связи страх смерти становится полностью бессмысленным, поскольку смерть несёт благо. Кроме того, она понимается философом не как переход в иное существование, а лишь как продолжение жизни человека. В.И. Несмелов пишет: «...Физическая смерть человека является не переходом в новую жизнь, а последним моментом действительной жизни» [7, с. 387].

Вообще жизнь человека трактуется философом как единое сочетание трёх составляющих: существования (то есть собственно физической жизни), смерти и воскресения, которое, по его мнению, обязательно ждёт каждого. Такое понимание соотношения жизни и смерти не только помогает человеку смириться с необходимостью физической смерти, осознать её благое значение, но и обрести надежду на жизнь вечную после воскресения.

Воскресение В.И. Несмелов трактует вполне традиционно - как продолжение существования в реальном теле, которое при этом будет лишено своего основного противоречия - противостояния физической и духовной составляющих. У воскресшего человека будет преобладать идеальная часть личности, он, наконец, обретёт целостность и избавится от противоречия, которое составляло несчастье его жизни.

Сам процесс воскресения учёный трактует достаточно оригинально, опираясь при этом на достижения естественных наук его времени, на открытия в области физики. Он говорит о том, что человек, естественно, не может воскреснуть в своём прежнем теле, поскольку оно уже истлело в земле, тем не менее, он всё же обретёт тело, возникшее в результате «того же самого творческого процесса жизни, которым образуются живые тела людей и в настоящий период их земного существования» [8, с. 408]. То есть новое тело человека образуется на клеточном уровне на основе тех воспоминаний о теле, той информации, которую сохранит душа. Такая трактовка процесса воскресения была достаточно нова для того времени, и, создавая её, Н.И. Несмелов снова демонстрирует свою способность отойти от некоторых догматов церкви, творчески интерпретировать их. К примеру, если принимать именно такой процесс воскресения, то становится неважным, как был похоронен человек - в освящённой земле кладбища, или за его пределами как самоубийца, или же вообще был кремирован. Главным выступает другое - как его душа сохранила память о своём существовании, как она пыталась преодолеть ключевое противоречие жизни в течение физической жизни, как она развивала свою нравственность и совесть, каким образом понимала собственную свободу воли.

Время воскресения человека В.И. Несмелов связывает со вторым пришествием Иисуса, которое трактует как обязательное явление грядущей истории человечества.

Как мы видим, В.И. Несмелов выстраивает свою концепцию человека, не разрушая основных христианских постулатов, однако позволяя себе их достаточно 
вольные трактовки. Это привлекло к его учению внимание современников, например, Н.А. Бердяева, который высоко оценил труд В.И. Несмелова и отмечал, что он «философски утверждает объективную истинность христианства» [2, с. 55]. Свобода в выстраивании собственной концепции человека определялась для В.И. Несмелова двумя факторами: во-первых, опорой на достижения науки того времени и применением в исследовании методов естественных наук; во-вторых, психологическим пониманием сущности взаимоотношений человека и Бога, опорой на представления о личности человека.

Итак, учение В.И. Несмелова о человеке развивалось в контексте метафизической психологии. Учёный выдвигает тезис о существовании в личности человека рокового противоречия: его материальная форма требует постоянного удовлетворения физических потребностей, диктует стремление к счастью и удовольствиям, а данное человеку по его природе осознание собственной идеальной сущности, Бога, требует преодоления этой физической зависимости. Преодоление оказывается не- возможным при жизни, и лишь смерть приводит человека к решению его проблемы. В контексте этой концепции В.И. Несмелов рассматривает такие составляющие человеческой личности, как счастье и страдание, самосознание, совесть, нравственность, физическое и духовное начала, свобода. Смерть понимается как последний момент физической жизни, необходимый перед её заключительным моментом - воскресением.

Концепция человека В.И. Несмелова отличается гуманизмом, бесконечной верой в лучшее в человеке, в то, что человек сам со себе наделён пониманием религии, осознаёт свою идеальную природу и стремится к Богу. Человек выступает как самостоятельная и самодостаточная личность, обречённая на постоянное и бесплодное преодоление своей физической сущности, но достойное лучшей жизни в будущем. Данная концепция отражает развитие в науке начала XX века антропоцентризма, признания того, что человек определяет собственный мир, все его составляющие - от лингвистической и социальной до духовной и религиозной.

\section{ЛИТЕРАТУРА}

1. Белов, А.В. Идея субъектности в «Науке о человеке» В.И. Несмелова / А.В. Белов // Новое понимание субъектности и проблемы философской инноватики: Мат. VI Российского филос. конгр. - Ростов-на-Дону: Дониздат, 2012. - С. 170-181.

2. Бердяев, Н.А. Опыт философского оправдания христианства (0 книге Несмелова «Наука о человеке») / Н.А. Бердяев // Русская мысль. - 1909. - № 9. C. 54-72.

3. Дворецкая, М.Я. Смысл жизни в религиозно-философской антропологии В.И. Несмелова / М.Я. Дворецкая, А.О. Турина // Вестник Православного СвятоТихоновского гуманитарного университета. Серия 4: Педагогика. Психология. - 2018. - № 48. - С. 121-127.

4. Дворецкая, М.Я. Структура и развитие самосознания в концепции психологии человека В.И. Несмелова / М.Я. Дворецкая, А.0. Турина // Личность В меняющемся мире: здоровье, адаптация, развитие. - 20206. - Т. 8. - № 1 (28). - С. 7-16.

5. Добин, А.В. Проблема человека в философии В.И. Несмелова: автореф. дис. . .. канд. филос. наук: 09.00.03. - СПб., 1996. - 20 с.

6. Замилов, В.Н. Метафизика человека в творчестве В.И. Несмелова: автореф. дис. ... канд. филос. наук: 09.00.03. - М., 2003. - 20 с.

7. Несмелов, В.И. Наука о человеке: в 2 т. Т. 1: Опыт психологической истории и критики основных вопросов жизни / В.И. Несмелов. - Казань: Центр. тип., 1905. -418 , IV C.

8. Несмелов, В.И. Наука о человеке: в 2 т. Т. 2: Метафизика жизни и христианское откровение / В.И. Несмелов. - Казань: Центр. тип., 1906. - 438, II с.

9. Поль, В.А. «Метафизика человека» в философско-религиозной антропологии В.И. Несмелова / В.А. Поль // Труды Дальневосточного государственного технического университета. - 2005. - № 140. - С. 170-182.

10. Сулема, А.А. Проблема телесности в философско-религиозной антропологии В.И. Несмелова / А.А. Сулема // Социальные и гуманитарные науки на Дальнем Востоке. - 2014. - № 4 (44). - С. 79-83.

11. Шпак, А.П. Проблема счастья в антропологии В.И. Несмелова / А.П. Шпак // Актуальные проблемы гуманитарных и естественных наук. - 2011. - № 7. C. 186-189.

(c) Фисенко Григорий Федорович (vipger@bk.ru).

Журнал «Современная наука: актуальные проблемы теории и практики» 